\title{
Journal of Architectural Education
}

\section{Creative Commons}

\section{Lluis J. Liñán}

To cite this article: Lluis J. Liñán (2018) Creative Commons, Journal of Architectural Education, 72:1, 42-43, DOI: 10.1080/10464883.2018.1410652

To link to this article: https://doi.org/10.1080/10464883.2018.1410652

曲 Published online: 12 Mar 2018.

Submit your article to this journal $\pi$

III Article views: 29

Q View related articles $\sqsubset$

$\bigotimes_{\text {CrossMark }}$ View Crossmark data $匚$ 


\title{
Creative Commons
}

\author{
Lluis J. Liñán \\ Polytechnic University of Madrid
}

This image depicts an experiment that was conducted at the Rice University School of Architecture in 2016 in a studio that tested the potential of appropriation as a design methodology. The experiment was based on the following premises: First, the students had to use drawings - plans and sections - as the main technique of design. Second, they had to transform an existing pool of drawings in editable format for the generation of their own designs. Stretching, copying and pasting, erasing, juxtaposing, and/or scaling where some of the operations they could perform on the existing graphic material. Finally, all the drawings had to be shared, including the various versions of their projects.

Following these premises, the studio was structured as a constant process of redrawing in which the progressive introduction of programmatic requirements, graphic material, and contextual constraints determined the evolution of each project. Duplicities and borrowings were employed as a trigger for multiple discussions on the architectural qualities of each version. This structure enhanced the students' ability to respond with agility to the questions posed in each step of the journey and to explore, through the language of the architectural project itself, the versatility of different formal, structural, and spatial systems vis-à-vis such questions.

\section{Author Biography}

Lluis J. Liñán studied architecture at Technische Universität Wien (TU Wien), Escuela Técnica Superior de Arquitectura de Valencia (Valencia ETSAV), and Escuela Técnica Superior de Arquitectura de Madrid (Madrid ETSAM). He is a professor at the Master in Advanced Architectural Projects at Madrid ETSAM, a PhD candidate at the Polytechnic University of Madrid, and was Wortham Fellow at the Rice University School of Architecture (2015-2017). Liñán's research focuses on the impact of digital dissemination media on architectural design, and his writing has been published in journals such as CIRCO, Bartlebooth, and PLAT. He is also founding member, along with Andrea Gimeno and Xevi Lluch, of rellam, a small and nomadic design cooperative. Their built and speculative work has been awarded several competition prizes and exhibited at the 2016 Venice Architecture Biennale. 


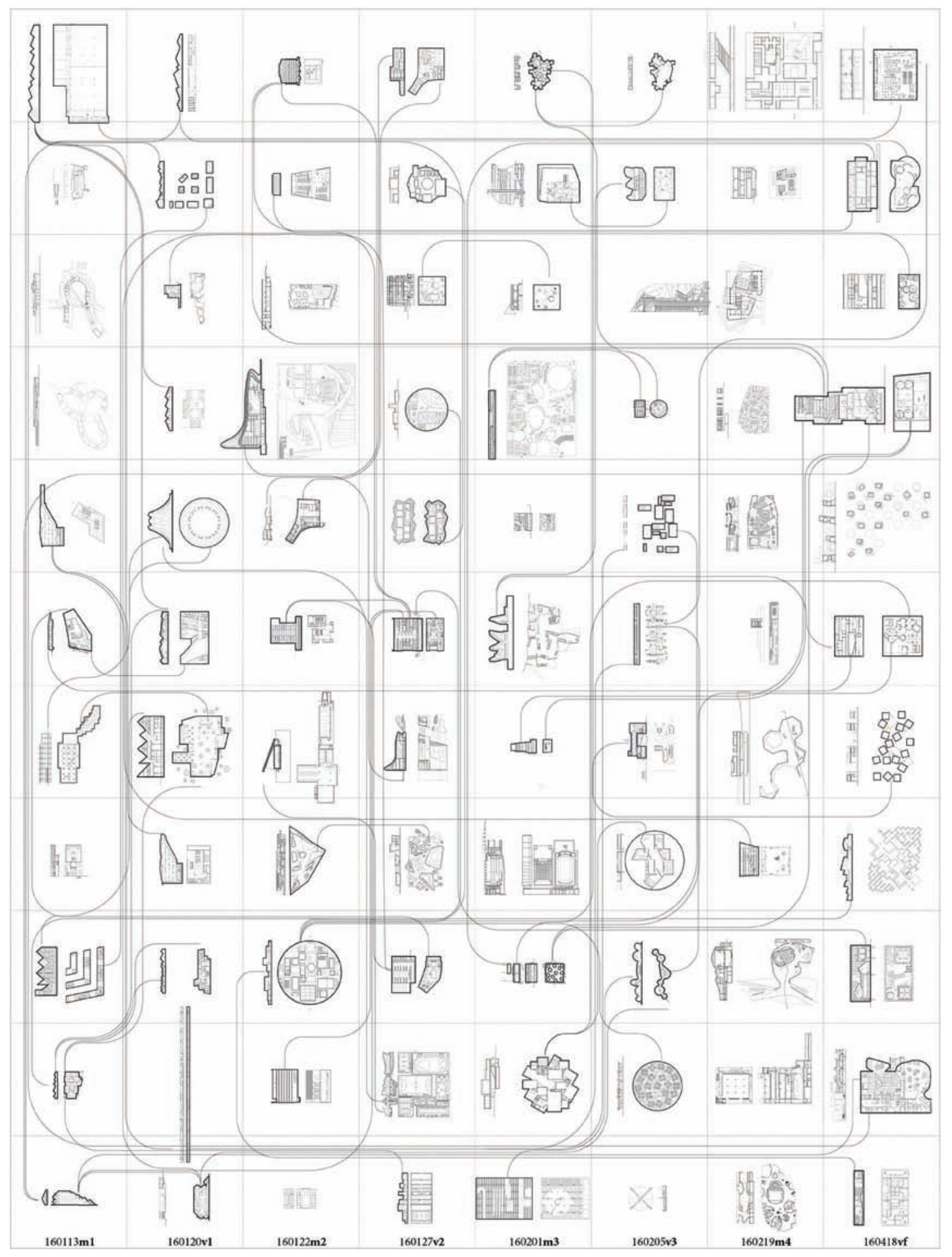

Lluis J. Liñán

Creative Commons: An Experiment in Projective Appropriation, 2016 Digital drawing using Rhino and Adobe Illustrator 